\title{
The Aesthetic Experience in Business English Translation under the Background of Internet
}

\author{
Qian $\mathrm{He}^{1}$ \\ ${ }^{1}$ Nanchang Business College of Jiangxi Agricultural University, Gongqingcheng, Jiangxi, 332020, China \\ Research on the Standardized English Translation of Jiangxi's Special Agricultural Products under the Background of "One Belt One \\ Road"
}

\begin{abstract}
Under the background of "Internet ", international cooperation between enterprises becomes more convenient and efficient. In the Internet platform, both enterprises can not only realize long-distance "face-to-face" communication, but also realize information exchange through various communication platforms. Compared with the traditional business model, business English under the background of "Internet" is more professional and targeted, so business English translation should not only accurately and effectively transmit business information, but also pay attention to the exchange of aesthetic experience between the two sides. By analyzing the practical application of business English translation, this paper puts forward three aesthetic experiences: harmonious beauty, overall beauty and cultural beauty.
\end{abstract}

\section{Introduction}

As a strong service language, business English refers to the language service provided in various business situations to ensure the normal conduct of business activities. Different from ordinary English, business English has significant differences in language form, expression, translation, requirements and purpose. [1] Business English usually exists in the form of letters, business contract heads, advertising language and so on in business activities, in which letters are mainly in the form of e-mail and letters, and the purpose is to exchange information between the two parties. Commercial contract is a legal instrument signed in order to clarify each other's responsibilities and obligations after both parties form a cooperative intention. English advertising is to promote the content and products of business activities. It is precisely because business English has different stylistic forms, so in the process of translation, the translator should also combine the relevant vocabulary, syntax, article content and so on, and adopt flexible and diverse ways to translate. In professional business situations, business English involves many technical terms, synthetic words and even foreign words. At the same time, because of the need of cooperation, business English often adopts some different kinds of sentence patterns, which examines the logic and integrity of the translator's thinking. It is worth noting that in international business occasions, because both sides of the cooperation come from different countries and have different cultural backgrounds, how to make English translation more accurate and aesthetic?

\section{Characteristics And Translation Of Business English}

\subsection{Characteristics of Business English}

\subsection{1. strong in speciality}

A prominent sign of business English is the precise use of professional words, which include professional words, acronyms, compounds, etc., such as FOB, CIF, 4P. The translation of professional vocabulary should not only clearly convey the meaning of the translation, but also conform to the expression of business occasions, so the translation skills are particularly demanding.

\subsubsection{Very formal}

Because of the different status and social relations between the two sides, language can be roughly divided into five styles: apathy, formal, casual, consultative and intimate. [3] In order to facilitate international trade cooperation, the use of business English is more common and easy to understand, but it should not be too colloquial and the content should be clear and accurate.

\subsubsection{Politeness and decency}

Language expression should respect each other's customs and culture as much as possible. The purpose of business cooperation is to realize the interests of both parties. Therefore, language expression can not easily make the

\footnotetext{
*Corresponding author's e-mail: 739960103@qq.com
} 
other party feel bad. Let each other understand the content of the information at the first time. However, because the object of business cooperation often comes from different countries and has different cultural backgrounds, the translator should master the cultural background of the other party before conducting business translation, and express the translation information in a way that the other party is easy to accept and understand.

\subsection{Translation methods}

\subsection{1. literal translation}

It is only the translator to translate according to the surface meaning of the article, the advantage of this way is that the information transmission is more smooth and accurate, but this translation requires higher cultural connotation of the article, that is, the cultural differences between the target language and the target language should be avoided as far as possible, otherwise the translator can not directly extract the meaning of the article. [2] For example virus, it first appeared in the field of medicine and was slowly applied to the field of computer programming, meaning "virus ", which requires translators to jump out of the medical profession and understand the connotation of words from the perspective of computer science. Because only by correctly understanding the meaning of each word can the translator grasp the whole content accurately.

\subsubsection{Extension}

It refers to the translator in order to express the meaning of the original text as much as possible, through the meaning of the extension on the basis of the original meaning. For example, some English words do not have a suitable explanation in the dictionary. If they are copied mechanically in the process of translation, the translated articles will be very stiff, recalcitrant and difficult to understand. [4] Therefore, when the translator can not translate according to the meaning of the word itself, he can use the extended meaning to transform the logical relationship and meaning of the original text.

\subsubsection{Interpretation}

When the above two cases are not applicable, the translator can use free translation in order to make the translation as close as possible to the original text in terms of spirit and artistic conception.

\section{Aesthetic Experience Of Business English}

\section{1. beauty of harmony}

In English expressions, two symmetrical or similar parts are usually linked by a conjunction to facilitate memory. There are four common forms:

Table 1 Four forms of connectives used

\begin{tabular}{|c|l|l|}
\hline 1 & Overlapping & $\begin{array}{l}\text { Overlap words are often used in English communication, that is, the } \\
\text { repetition of the same words, so that the expression is as compact and } \\
\text { clear as possible, such as "by and by", "diamond and diamond". }\end{array}$ \\
\hline 2 & Syn repetition & Connect two words of the same meaning with "and". \\
\hline 3 & Words of rhyme & $\begin{array}{l}\text { A group of words contains two or more words that begin with } \\
\text { consonants. }\end{array}$ \\
\hline 4 & Words of end rhyme & $\begin{array}{l}\text { A set of words contains two or more words with the same stressed } \\
\text { vowel at the end and the subsequent consonant. }\end{array}$ \\
\hline
\end{tabular}

The rhyme and rhyme in English expression will create a kind of language music effect, give people pleasant and pleasant hearing feeling. In business situations, these four expressions of English can be used and converted flexibly. The neat melody and bright rhythm brought by these four ways will make business activities carry out in a relatively relaxed and pleasant environment, which is more favorable and successful.

Language is an art, and the same sentence will show different expression effects through different tone, wording and arrangement. The high quality business translation should be based on the original meaning, the sentence as soft and harmonious as possible, so that the information transmitted can be more easily accepted by the partners. 


\subsection{The Beauty of the Whole}

Although English grammar, sentence structure, tense and so on can be used flexibly, the integrity of the article does not lie in the accumulative superposition of a single word, but each word has more organic combination of grammar, structural order, sentence pattern and so on, forming information with certain meaning and context. However, under the influence of the origin of traditional culture and writing, some conventional words can not grasp their meanings literally, such as "white elephant", their consciousness is not as simple as superficial understanding, but a heavy burden. The cost of raising the "white elephant" is said to be very high, so a king gave him a" white elephant", and asked him to keep it well "in order to complete the order of raising, clear the family money, and over time," white elephant" is understood as a burden and burden. So when we read the word "white elephant"", it seems that there is a picture of the minister raising elephants, vivid and interesting, thus giving people the enjoyment of beauty, unforgettable.

\subsection{Cultural Beauty}

Because of the obvious differences in national psychology, regional culture and mode of thinking between China and the West, the cultural connotations transmitted in English translation are also different. Chinese stresses "parataxis ", that is, the meaning can be expressed correctly, while English stresses" hypotaxis "and has strict requirements for the formation of words and sentences. Under the influence of national psychology, there are significant differences between China and the West in the views of other things, such as magpies. In the eyes of Chinese people, magpies have many children, symbolizing auspiciousness, while Westerners do not think so. They feel magpies chirp, very noisy and verbose. The Chinese regard the dragon as a fairy beast and the ancient times as a symbol of imperial power, but Westerners regard the dragon as the embodiment of evil. Westerners think that the number "13" is unlucky, but in China the number "4" is regarded as unknown. Under the influence of Chinese pronunciation, the pronunciation of the number " 4 " is similar to that of Chinese "dead ". In addition, the Chinese advocate even numbers and think that the numbers "6,8,9" all symbolize auspicious and smooth. It can be seen that the cultural differences between China and the West have a great influence in English expression and translation. The translator should feel the cultural charm in the translation on the basis of respecting the cultural background of the other party, so as to endow the translation with a unique cultural connotation.

\section{CONCLUSION}

With the deepening of international exchanges and the increasing competition of international trade, business English translators should constantly improve their own quality, constantly explore the aesthetic experience in business English, so as to further enhance their professional competitiveness and promote the development of the industry.

\section{Acknowledgment}

This work was supported by the research on the Standardized English Translation of Jiangxi's Special Agricultural Products under the Background of "One Belt One Road"

\section{References}

1. Yu,J.(2020)An Inquiry into Cultural Connotation in English Language Literature Education — A Review of English Language Literature and Culture[J].News enthusiasts.

2. Qian,G.L.(2004)Aesthetic Linguistics[M].Higher Education Press.

3. Su,L.(2018)Language Skills and Humanities Education-Reform of Human Culture Teaching Based on Comprehensive English Course of English Major in Shanghai Foreign Studies University[J].Foreign Language Teaching Theory and Practice.

4. Li,J.(2007)Review and Reflection on the Development of Contemporary Chinese Translation Aesthetics[J].Journal of Renmin University of China.

5. Gao,L.M.(2020)A Comparative Analysis of Style Characteristics of Business English and Daily English Translation[J].Modern vocational education.

6. Liu,L.M.(2020)A Study on Translation of Business English Letters in Cross-Cultural Context[J].English Square. 